\title{
A honRa perdida de Rafaela Sandoval na inde- PENDÊNCIA (PoPAYÁN, 1821-1823)
}

Jaime de Almeida*

jaimeida@terra.com.br

REsumo: O processo por estupro aberto por Teresa Laso contra o coronel José Concha mostra aspectos pouco discutidos da Independência: a expressão escrita juridicamente estereotipada de gritos, falas, gemidos e silêncio, carregados de ressentimento. $\mathrm{O}$ processo se desenrola enquanto a guerra prossegue alimentando ressentimento, exigindo mais e mais recrutas, gado, cavalos, suprimentos, dinheiro.

Palavras-Chave: Independência, Colômbia, Popayán, estupro.

No Archivo General de la Nación, em Bogotá, seção República, fundo Asuntos Criminales, tomo 80, o processo Contra el Señor Intendente del Cauca por atribuirsele varios excesos. Año 1822 tem como principal documento um memorial entregue ao Excelentíssimo Senhor Libertador em Popayán, a 7/02/1822 por Teresa Laso [f. 6 a 7v]:

[...] Deus trouxe V. Excia. a esta cidade, e o trouxe como ai, como Protetor, e como Libertador. O mesmo Deus dá impulso ao meu coração, alenta minha esperança, e me assegura a justiça. Encontro-me ofendida, Excelentíssimo Senhor, na pessoa de uma filha donzela, vítima inocente dos seus poucos anos. O senhor Governador desta Província, coronel José Concha, em junho [sic] do ano passado [...] sob o pretexto de que sou uma mulher devotada ao sistema espanhol e prejudicial ao republicano, me fez conduzir com escândalo a um quartel, junto com minha filha Rafaela, como delinqüentes. [No silêncio da noite] aparecem na prisão os oficiais Martínez e Guerra à meia noite, e arrancam de meus braços a minha desgraçada filha, alegando que deviam interrogá-la. Apresentada ao senhor Concha, o resultado é o que Vossa Excelência vai ouvir: ele fica sozinho com ela; puxa o sabre; coloca-o sobre a sua garganta; faz ameaças espantosas, com as expressões mais caluniosas; a inti-

\footnotetext{
Professor do Departamento de História da UnB.
} 
mida; faz com que ela perda os sentidos; e minha filha é violada, estuprada, perdida. O depositário da Lei. Aquele que tem encomendada a força do Governo e a justiça para a segurança pública. [...] É ele que ataca, viola, e fere as virtudes naquilo que é mais delicado e sensível. [...] Minha filha, entre a dor e o choro, não pode ocultar-me a violência e sua desgraça. A sensibilidade de Mãe; a iniqüidade perpetrada; o furor do desenfreio lascivo [...] fizeram-me produzir algumas expressões que deram transcendência do acontecido na cidade. Um abismo, senhor, traz outro. Para que nada viesse a público, e para sepultar meu opróbrio e o de minha filha, [o Intendente José Concha] tomou a decisão violenta do desterro e de imediato nos fizeram sair a pé, cheias de angústias, de trabalhos e misérias, até o porto de Buenaventura para onde nos destinaram, certamente para que morrêssemos e triunfasse o crime [...] A notícia certa da vinda de Vossa Excelência e a consideração de que aqui tenho parentes e pessoas piedosas cientes de minha inocência que poderiam contar-lhe, foi sem dúvida o que levou o senhor Concha a dar-me passaporte (que apresento a V.E.) sem que eu o tivesse pedido; persuadido certamente também que, amedrontada por seu recente título de Intendente que o confirma no Governo, eu sufocaria minhas queixas para não expor-me ao furor de sua vingança. Eu o faria Excelentíssimo Senhor, se não pudesse falar com um Presidente justo e virtuoso, que faz a felicidade dos Povos e me dará segurança com sua proteção que reclamo sob os auspícios da justiça e da lei. Pelo desterro, senhor, minha família perdeu seus poucos recursos; tudo na casa foi roubado e a miséria acaba de selar nossas desgraças. [Pede ressarcimento de todos os seus prejuízos pelo culpado] Sou mulher, senhor, e infeliz. Não posso lutar contra um poderoso. Ponho nas mãos de V. Excia. a minha justiça. Tive que mendigar esta representação fora da cidade. Ninguém se atreve a indispor-se com a principal autoridade, nem a sofrer o ressentimento de seu temperamento; por isto é que V. Excia. desconhece outras coisas [...] principalmente, tendo ele manifestado o ódio que tem a toda Popayán, cidade que ele ultrajou, insultou até por comunicado público, cobrindo de opróbrio a todo homem, sem exceção, que calo por prudência.

Teresa Laso era analfabeta. Não sabemos quem redigiu e assinou por ela o texto, cujo estilo demonstra boa cultura clerical e forense. Três dias depois, o secretário do presidente Simón Bolívar encaminha ao juiz político de Popayán a ordem de examinar a veracidade daquelas queixas contra o Intendente José Concha, suspendendo o foro militar de quem precisasse ser investigado. [f. 8]. A 11/02/1822 o juiz Vicente Xavier Arboleda interroga o subtenente Manuel María Guerra y Nieto, do batalhão Vargas [f. 10]. Este confirma que em junho [sic] de 1821 foram presas Teresa Laso, sua

História Revista, Goiânia, v. 13, n. 2, p. 353-377, jul./dez. 2008 
filha Rafaela e outras tantas mulheres na sua casa [do declarante], cuja chave lhe foi confiscada. O finado capitão Martinez lhe trouxe ordem do governador José Concha de levar uma certa Rafaela para prestar depoimento. A moça resistiu, ajudada pela mãe. Chegando à casa do governador com Rafaela, o capitão Martinez lhe propôs sair e voltar mais tarde, de modo que a moça ficou sozinha com o governador. Logo mais eles a encontraram na rua, conduzida por um soldado assistente do governador, cujo nome ele ignora. O capitão Martinez trancou-a de novo com sua mãe e as outras mulheres, e todas saíram imediatamente para o desterro. Perguntado se foi aberto algum processo contra Rafaela Sandoval e as demais mulheres, diz que não sabe; e também ignora se outros oficiais do exército podiam ter conhecimento do fato [o interrogatório da jovem].

Dois dias depois, o juiz vai à casa de Teresa Laso interrogar María Rafaela Sandoval, que está de cama [f. 10v-11]. Ela declara que em junho [sic] de 1821 foi conduzida à casa do doutor Antonio Arboleda pelo capitão Martinez e pelos subtenentes Domingo Arboleda e Manuel María Guerra, e depois levada com sua mãe e outras mulheres à loja deste último. À meia noite, foi retirada dali pelos oficiais Martinez e Guerra, este último golpeou sua mãe que a ajudava a resistir; levaram-na à casa do senhor governador Concha, dizendo que iam tomar-lhe declarações. Chegando à casa, ele a fez prestar juramento em presença dos citados oficiais, que logo se retiraram. O governador começou a perguntar com quais patianos [moradores do vale do Patía] sua mãe tinha contato; com quem tinha ido ela [Rafaela] encontrar-se nas terras comunais do Ejido; se sua mãe tinha ido ao Callejón [beco] para contar os soldados da tropa. Ela respondeu que sua mãe fora ver o general Pedro León Torres por conta de uma representação feita pelo presbítero José María Chacón; e que ela mesma ficara em casa fazendo cigarros, e não fora ao Ejido. Então, o governador a fez passar a um outro cômodo que tinha uma cama, fazendo as mesmas perguntas, e mandou-a deitar-se. Ela resistiu, ele a agarrou com força, pôs a espada em seu peito e a obrigou a executar seus execráveis desejos. Depois recomendou que ela não contasse à sua mãe e, quando chamou um soldado para devolvê-la à prisão, chegaram os oficiais Martinez e Guerra que a conduziram. Chegando lá, contou imediatamente à mãe o que acontecera. A sua assinatura lembra aquela do memorial apresentado por sua mãe a Simón Bolívar.

Em 07/03/2002, a Secretaria do Interior e Justiça recebe em Bogotá o processo com esses depoimentos e mais alguns, de natureza militar, relacionados com a conduta do Intendente José Concha, por ordem de Simón Bolívar. Por decreto do vice-presidente Francisco de Paula Santander as questões de ordem militar serão tratadas à parte; o processo político se encaminha à Cor- 
te Superior de Justiça [f. 13]. Esta segue a orientação do fiscal Borrero que, salientando a gravidade das acusações, sugere devolver o processo a Popayán, ampliar o número de testemunhas, inclusive em outras cidades, convocar o Intendente José Concha a depor em Bogotá, deixando um substituto interino [f. 14-15]. Toda a base jurídica do processo remete à legislação espanhola que só seria substituída por códigos republicanos bastante mais tarde.

Em 11/05/1822, o Intendente interino, Francisco Xavier Cuevas, ouve a senhora Teresa Laso. Ela nomeia as outras mulheres que estavam presas naquela noite: sua mãe Narcisa Rosas, sua irmã Vicenta Laso, sua sobrinha Juana Paula Sandoval, Candelaria Sánchez (falecida) e Luz Bermúdez. Indica o oficial Ludovico Inglês, que está agora em Pasto, como a única pessoa que com certeza viu sua filha Rafaela ser conduzida à casa do Intendente José Concha. Declara que uma filha de José Joaquín Bonilla também foi estuprada pelo Intendente, e que tal informação poderá ser confirmada por Fernando Sánchez e pela própria moça [f. 17].

No mesmo dia, Fernando Sánchez declara que sua sobrinha María Baltazara Bonilla, órfã desde janeiro de 1820 , nunca foi molestada. No dia seguinte, Baltazara Bonilla, de 17 anos, declara que esteve apenas uma vez com o coronel Concha, por ter sido acusada de não aceitar moedas republicanas, e que não sofreu tentativa de violação [f. 17v-18]. Em 23/06/1822, estando na cidade, o subtenente Carlos Ludovico relata que naquela noite de um ano atrás ele estava na Casa de Contadoria, diante da loja em que estavam presas as mulheres; ouviu gritos de uma delas e alguém lhe disse que Rafaela tinha sido levada à presença do governador Concha. Não se recorda bem, poderiam ser $22 \mathrm{H} 00$ ou $22 \mathrm{H} 30$. Não viu quem a conduzia; pelas $23 \mathrm{~h}$ Rafaela já voltara e chorava junto com sua mãe; ele não soube a razão do choro. Recorda-se de ter visto, naquela ocasião o capitão José María Martinez e o subtenente Manuel María Guerra [f. 18v-19v].

Dois dias depois, o subtenente Manuel María Guerra declara que retirou Rafaela Sandoval da prisão pelas $23 \mathrm{H} 00$ e, tendo-a deixado na casa do governador Concha, voltou a vê-la cerca de meia hora depois na rua, reconduzida à prisão por um soldado. Ela vinha em profundo silêncio, sem nenhum sinal de ter sofrido qualquer dano ou ultraje. Tendo entrado e falado com sua mãe por uns cinco minutos, esta começou a acusar o governador de ter deflorado sua filha. Havia duas moças com sobrenome Sandoval e o capitão José María Martinez sabia que Rafaela é quem devia ser interrogada [f. 19v-20].

Em 28/06/1822, o juiz político de Cali, Félix Vergara, interroga Luz Bermúdez naquela cidade. Ela declara ter sido presa à noite da véspera de 
Santa Ana [24/07/1821]. Pelas 10 ou 11H00, apareceram três sujeitos buscando por uma das Sandoval; uma delas [Juana Paula] se escondeu às suas costas e Rafaela resistia a sair sozinha, pedindo que sua mãe ou sua tia a acompanhasse. A avó, a mãe e a tia também opunham resistência; o capitão Martinez ameaçou-as com o sabre e machucou a avó [Narcisa Rosas]. Quando voltaram, os três sujeitos disseram a Teresa Laso: "aí está sua filha, ninguém lhe tirou nenhum pedaço". Logo saíram desterradas a Cali. Rafaela contou à mãe que o governador Concha perguntava sobre papéis entregues aos patianos, empurrou-a para a cama e, ameaçando-a com o sabre contra o peito, a estuprou. Rafaela sempre foi muito recolhida e honrada, com boa reputação; por conta do ocorrido, sua mãe pensa depositá-la no convento das Carmelitas de Popayán [f. 22-23].

Em Popayán, a 12/07/1822, Estevam Pérez declara que Rafaela Sandoval "já teve suas distrações e manteve tratos ilícitos" e que sua má conduta é de conhecimento público [f. 24]. Já Francisco Villaquirán e Camilo Guevara declararam que Rafaela Sandoval tinha boa conduta moral antes do estupro [f. 24 -25]. O Intendente interino, Francisco Xavier Cuevas, devolve o processo à Corte Superior de Justiça a 20 de julho. Em Bogotá, a 13/ 08/1822, o fiscal Borrero reavalia as acusações feitas contra o Intendente José Concha, considera provável o estupro, e acrescenta:

[...] Não passarei em silêncio o concubinato adulterino que segundo dizem mantém o mesmo senhor Intendente com escândalo público, nem a insubordinação que teria fomentado entre os escravos com uma cega e ilimitada proteção, razão do abandono da agricultura, e outros males como $o$ assassinato de homens inocentes, entre eles um camponês, barbaramente fuzilados quando entravam na cidade, ignorando uma resolução publicada pelo tenente coronel Pedro Murgueitío por ordem do senhor Concha; o laxismo consentido e dissimulado do capitão Ignacio Rengifo, os excessos tolerados do comandante da costa ángel María Varela, do tenente que governou a região do Raposo, Fernando Fernández, e dos demais oficiais e juízes apontados por depoimentos tomados no Vale do Cauca. Tudo isto deve ser juntado ao processo [...] Não há que ponderar as espantosas conseqüências que traria a impunidade de excessos tão monstruosos, comparáveis apenas (segundo a expressão de S. Excia. o Libertador Presidente) aos que cometeram os espanhóis [...] [f. 26-28].

Agora o processo começa a incorporar declarações de apoio ao Intendente José Concha. O cabildo de Caloto (05/10/1822) enfatiza o seu papel decisivo na guerra contra os realistas; é implacável quando necessá- 
rio, como ao enfrentar as quadrilhas remanescentes das tropas realistas do comandante Calzada, mas sempre persuasivo, amistoso, moderado e justo. Somente os egoístas podem queixar-se pelas contribuições que ele recolheu para abastecer as tropas republicanas no Vale do Cauca [f. 38-39]. Em 27/09/1822, (a pedido) o presbítero doutor Manuel María Urrutía y Quijano, principal autoridade eclesiástica vinculada à República na região, atribui a José Concha grandes méritos na vitória contra as tropas realistas do general Calzada e no abastecimento das tropas que marcharam ao sul. Também a pedido, o general José María Cancino, governador e comandante da província do Chocó, enfatiza os feitos militares de José Concha na defesa da causa patriótica no Cauca [f. 68].

Seguem depoimentos sem data, tomados em Popayán. O procurador geral, José Rafael Arboleda, detalha iniciativas do Intendente José Concha visando a recuperação da região, como uma doação à escola lancasteriana de Popayán [f. 69]. José Diago cita a Casa da Moeda, escolas, colégio, hospitais, renda de tabacos, melhoria de caminhos, etc. [f. 69v-70]. A 1/03/1823, o coronel José Concha solicita ao bispo de Popayán uma declaração acerca de sua conduta pública e privada [f. 71]. O promotor fiscal da diocese, Agustín Sarasti, relata que já foi enviado ao vice-presidente da República um apelo à permanência do coronel José Concha no seu cargo. A cidade encara a partida do Intendente como um retorno às desgraças passadas. Em nome de todo o Clero, o fiscal elogia a conduta pública e moral do digno Chefe, um dom do céu a quem a Cidade agradece pelo interesse que ele tem tomado para levantá-la das ruínas em que se encontra [f. 71v-72]. No mesmo dia, don Salvador Jiménez confirma as palavras do promotor fiscal. [72-72v].

Um novo memorial de Teresa Laso chega à Suprema Corte em abril de 1823; no momento temos acesso apenas à última página. Afirma que todos temem o coronel José Concha e não ousam dizer a verdade, mas ela confia em Deus, protetor dos humildes [f. 60]. A 13/05/1823, José Concha está em Bogotá, destituído de suas funções de comando político e militar apesar da rebelião em curso em Pasto, e solicita com firmeza o direito de ser ouvido [f. 61]. Foi interrogado em 31 de maio [f. 81-83]:

Declara-se casado, 38 anos, natural de Rosario, província de Cúcuta; conhece a acusação feita por Teresa Laso e se declara inocente. O general em chefe ordenara prender Teresa Laso, sua irmã, sua filha Rafaela e outras mulheres inimigas da Liberdade; e interrogar Rafaela Sandoval que conversara naquela tarde com um(a) espiã do inimigo, enquanto Teresa Laso, numa loja à esquerda da ponte do Humilladero, contava os soldados do 
exército que por ali passavam. Por isto mandou os oficiais Manuel María Guerra e José María Martinez trazer Rafaela Sandoval; ela prestou juramento diante desses oficiais na Sala de Despacho e foi interrogada em segredo porque os interrogatórios relativos às operações do inimigo não se fazem em público e devem ser conduzidos exclusivamente pelos chefes militares. Deixou-a sozinha na referida Sala de Despacho, chamado para refrescar-se na sala principal; encontrando no corredor os oficiais, ordenou ao capitão Martínez que entrasse na Sala de Despacho e a interrogasse. Ela negava tudo, alegando preferir a morte a mentir, "pois não havia conversado com nenhuma espiâ" [sic, f. 82]. De volta à Sala de Despacho retomou o interrogatório e, não obtendo a informação que queria, ordenou ao mesmo capitão Martínez, que continuava no corredor, reconduzir a Sandoval ao quartel onde estavam as outras presas. De tudo prestou contas ao general-em-chefe, Pedro León Torres, que ordenara tais diligências; se naquela ocasião tivesse ocorrido algum excesso, as vítimas deveriam ter-se queixado àquele general [falecido em agosto de 1822].

As mulheres estavam detidas por ordem do general-em-chefe, como suspeitas e inimigas da causa. A diligência mais importante a fazer era o interrogatório de Rafaela Sandoval e de sua mãe, Teresa Laso, vista na ponte do Humilladero em atitude suspeita. A superior autoridade militar só atribui tarefas como esta a subordinados de inteira confiança. Algumas pessoas tinham visto a Sandoval falando com o espião [sic, f. 82v]. Quanto ao tempo de permanência da Sandoval na casa para interrogatório, o coronel José Concha aponta contradição entre os depoimentos do capitão Martínez e do oficial Guerra. Repete que o interrogatório e o desterro das mulheres para Cali eram ordens do general Pedro León Torres; em caso de irregularidade, o general teria visto e mandado corrigir. O mesmo general deportou mais tarde dois outros grupos de mulheres realistas. A cidade podia sofrer um novo ataque inimigo e as mulheres suspeitas eram realistas notórias, como atesta uma comunicação feita ao vice-presidente da República, Francisco de Paula Santander, a 7/08/1821 sobre anotações de um espião encontradas no Ejido. As declarações do subtenente Manuel María Guerra acerca do tempo que tomou o interrogatório demonstrariam a falsidade do depoimento da Sandoval: entre a Sala de Despacho e a porta do saguão há dois balcões internos e 15 ou 16 degraus a percorrer.

A ordem de desterro de todas as mulheres presas a Cali teria sido dada oralmente pelo general-em-chefe. Elas foram depois enviadas ao porto de Buenaventura (na costa do Pacífico) pelo coronel José Maria Cancino, seu substituto no comando, enquanto ele (José Concha) viajava a Bogotá a 
mando do general-em-chefe para informar o vice-presidente acerca do estado do exército. Ao saber do envio das mulheres a Buenaventura, ordenou ao tenente-governador de Raposo fornecer-lhes passaportes para que retornassem a Cali. Permaneceram ali até que, por ordem do presidente da República, ele autorizou o seu retorno a Popayán, pois os motivos do desterro já não existiam. O coronel José Concha conhece as outras acusações que lhe foram feitas: de tomar arbitrariamente gado e cavalos aos proprietários por exigências da guerra, tratar com dureza os habitantes da região, apoiar os escravos e proteger subalternos seus; e contestará a seu tempo cada uma destas acusações em particular.

O documento seguinte [18/06/1823, f. 87-89, assinatura ilegível] contém as considerações finais de um novo promotor, muito favoráveis ao intendente José Concha. Informa que por decisão do ministro Vicente Azuero o depoimento de Teresa Laso não foi considerado necessário. Há dois delitos a averiguar; o primeiro é a acusação feita por Teresa Laso, de estupro violento contra sua filha Rafaela Sandoval. O Promotor não endossa tal acusação, pois não há nenhuma evidência de estupro nem de violência e, além do mais, a acusação teria sido retirada. O desterro de Teresa Laso e outras mulheres não teria sido arbitrário, pois elas eram suspeitas e tal precaução visava melhor defender a cidade; ademais que fora verbalmente ordenado pelo general-em-chefe. Antes que o congresso constituinte publicasse as novas leis, ${ }^{1}$ quase todos os chefes e governadores recorreram eficazmente a estes e a outros arbítrios que somente agora parecem repugnantes. Teresa Laso acusou também o senhor intendente Concha de tentar violentar Baltazara Bonilla; mas as testemunhas por ela indicadas nada mais declararam que a falsidade da Laso, desmascarando sua malícia; pode-se presumir que com a mesma falsidade ela $o$ acusou de forçar sua filha.

O texto contrapõe sistematicamente o Senhor Intendente, o Coronel José Concha, à Laso e à Sandoval. Sabemos apenas que elas preparam cigarros em casa e residem perto das terras coletivas do Ejido. A desproporção de forças é visível.

Passando ao segundo bloco de acusações, o Fiscal opina sobre a denúncia de "encobrimento de crimes perpetrados pelos funcionários da Intendência do Cauca". É bem verdade que ocorreram excessos, mas há que se verificar se eles chegaram ao conhecimento do senhor Concha, e se ele protegeu os responsáveis ou deixou de tomar providências. Algumas declarações confirmam a primeira alternativa, mas ninguém acusa o senhor Concha de ter deixado de cumprir suas funções; ao contrário, muitos de- 
claram que ele mandou averiguar os delitos de que tomou conhecimento. Por isto, o Fiscal não pode endossar tal acusação. "Há crimes em todas as partes da República, mas se eles ocorrem, e são conhecidos, não se justifica chamar aos tribunais as autoridades, a menos que elas os encubram ou deixem de averiguá-los."

Inicialmente, tratava-se de um estupro violento e ocultação de delitos dos funcionários da Intendência; logo se acrescentou a acusação de tentativa de estupro contra Baltazara Bonilla. Depois apareceram denúncias de amancebamento, ilimitada proteção aos escravos. O processo tomou o formato dos antigos Juízos de Residência, ${ }^{2}$ expressamente proibidos por lei. Quanto ao crime de amancebamento, o Fiscal apela às normas espanholas que impõem o silêncio a todos, com exceção do marido ofendido, e apenas no caso em que ele se pronuncie. Como não aparece comprovadamente nos autos nenhuma conduta criminal ou qualquer fato particular em prejuízo da sociedade ou dos direitos dos senhores de escravos, também nestas matérias nada existe a fazer contra o senhor Concha.

O Fiscal conclui: pela força dos documentos comprobatórios, dos depoimentos de altas personalidades, como o bispo, o provisor, o secretário eclesiástico, os membros do Cabildo e demais pessoas principais de Popayán, o Senhor Intendente Coronel José Concha deve ser declarado inocente. Para a Corte Superior de Justiça - é o que ele espera e sugere - será sumamente satisfatório o fato de não encontrar nenhum delito na causa instruída contra um Intendente da República.

Seguem os documentos anexados ao processo por José Concha em sua defesa. O primeiro é uma carta endereçada ao general Pedro León Torres pelo capitão Tomás Cipriano de Mosquera em Popayán a 26/07/1821 [f. 90]. O jovem e aristocrático capitão relata que à noite da véspera cumpriu ordens do comandante geral da província [coronel José Concha], prendendo algumas mulheres sediciosas e inimigas da boa ordem. Encontrou Josefa López dormindo em sua loja com um homem que fugiu para o Ejido por uma porta falsa, deixando papéis comprometedores. A mulher confessou que se tratava de José María (Seijas?), oficial do Inimigo. Os papéis revelam que Seijas veio fazer comércio clandestino e conhecer o estado em que se encontra a cidade. O capitão Mosquera prendeu também a irmã de Josefa, Tomasa López, esposa de Juan A. Santa Cruz, e outras mulheres notoriamente suspeitas de manter contato com o inimigo.

O segundo documento é cópia oficial de um trecho da carta enviada a 7/08/1821 pelo coronel comandante geral do Departamento do Cauca José Concha ao vice-presidente dando conta, por ordem do general Pedro 
León Torres, do estado em que se encontravam o exército, as operações e o território [f. 91]:

\begin{abstract}
A guarnição que permaneceu em Popayán não é suficiente, em razão da antipatia generalizada contra o sistema liberal; para não molestar V.S., não me referirei a certos acontecimentos muito recentes daqui. Por exemplo, a 27 de julho, prendemos uma mulher que anotava quantos soldados nossos faziam exercícios militares; naquela noite ordenei ao capitão Mosquera prender uma outra em cuja casa ele encontrou um suspeito que, segundo confessou a mulher, era um oficial godo [espanhol, realista] que acabara de chegar do vale do Patía. À tarde daquele mesmo dia 27, o general e eu fomos ao Ejido onde encontramos dois espiões do inimigo que se dirigiam à cidade. É provável que boa parte da surpresa do coronel Infante [ferido e preso por guerrilheiros realistas no vale do Patía quando procurava por gado e cavalos] se deva às informações dadas ao inimigo por uma mulher daqui. O general decidiu garantir a segurança da cidade retirando daqui as famílias mais perversas e por isto eu as fiz deslocar a Cali; mas seria preciso retirar todo o povo baixo, principalmente as mulheres.
\end{abstract}

Desde a chegada das primeiras notícias acerca da formação de uma junta patriótica em Quito, em agosto de 1809, até o momento em que se desenrolou o processo que temos em mãos, Popayán foi disputada por tropas realistas e patrióticas; durante esses doze anos, a presença realista foi mais constante. A maioria da população mantinha laços familiares, religiosos e comerciais com dois baluartes da causa realista: o vale do Patía e a cidade de Pasto. (Em junho de 1822, cerca de um ano depois do suposto estupro de Rafaela Sandoval, e quatro meses depois que Teresa Laso escreveu a Simón Bolívar pedindo justiça, o intendente José Concha e o tenentecoronel Genaro Ayarsa ouviram dizer que certas mulheres estariam oferecendo aos soldados uma aguardente preparada no Ejido com "adormidera ou borrachero". ${ }^{3}$ Segundo Josefa Villaquirán, analfabeta, o subtenente Joaquín Flor lhe disse "que na casa dela, ele tomava aguardente com satisfação, porque ela era uma patriota; mas que ali por San Agustín e pelo Empedrado, estavam botando umas sementes na aguardente que serviam aos soldados". Persistia a desconfiança em relação às mulheres que viviam e trabalhavam junto às terras comunais do Ejido). ${ }^{4}$

O terceiro documento anexado pelo Intendente [f. 92] é o depoimento de Juan de Dios Olano, ministro tesoureiro do Exército e Fazenda. ${ }^{5}$ Na casa do Comissário Geral de Guerra Antonio María Ramírez, onde se 
hospedava o coronel José Concha, conversando sobre o motivo que o trazia a Bogotá, ele ouviu do tenente-coronel Fernando Fernández o seguinte:

[...] Quando a mulher de Popayán (a quem se supunha ter estuprado o senhor coronel José Concha) [sic] seguia com as outras, rumo ao porto de Buenaventura, na condição de desterradas por ordem do senhor coronel José Maria Cancino, ele exercia a função de Tenente Governador e por isto foi informado de que a mãe falava da violência feita contra sua filha pelo senhor Concha; e como se tratava de um Chefe como esse, mandou-a chamar para averiguar os fatos. Como a mulher confirmou o que vinha dizendo, ele interrogou também sua filha Rafaela Sandoval, acerca do modo com que se havia executado o estupro. Ela respondeu que era falso, e que sua mãe [...]

O documento seguinte [f. 93] completa o anterior. O próprio tenente-coronel Antonio María Ramírez relata que, no dia 6/05/1823, seu hóspede, o senhor coronel José Concha, foi visitado à noite pelo tenente-coronel Fernando Fernández e pelo ministro contador [sic] Juan de Dios Olano, e:

[...] tratando sobre a vinda do referido senhor Concha à capital para ser julgado pelo Tribunal de Justiça, em razão de uma queixa dada por uma Laso de Popayán, dizendo que the havia estuprado uma filha com violência, o referido tenente-coronel Fernández expôs que, quando esta mulher foi com outras ao porto de Buenaventura na condição de desterradas, por ordem do senhor coronel José María Cancino, ele era o Tenente Governador e as recebeu. A Laso falava do estupro de sua filha, atribuindo-o ao senhor Concha; e como tais expressões desacreditavam um Chefe, chamou-a para averiguar; ela manteve o que dizia, afirmando que era fato. Desejando certificar-se, fez comparecer sua filha Rafaela Sandoval, que se dizia estuprada, e a interrogou sobre o fato, e de que modo se havia executado. Ela respondeu que era falso, e que sua mãe o dizia para prejudicar o Governador Concha, porque não encontrava outra coisa [...]

A seguir o advogado Juan Nepomuceno Aguilar, secretário da Intendência do Cauca, atesta que S. Excia. o Libertador, Presidente da República, comunicou por meio do Secretário Geral, a 4/03/1822, ao senhor Intendente Governador do Departamento, coronel José Concha, entre outros assuntos, o seguinte [f. 94]:

S. Excia. o Libertador está plenamente satisfeito com a atividade e zelo com que V.S. tem dado conta de todas as solicitações suas para suprimento, equipamento e subsistência do exército. Tudo o que se tem pedi- 
do a V.S. no Departamento sob seu comando, V.S. tem resolvido sem colocar empecilhos, antes facilitando tudo e prestando serviços tão correta como oportunamente. Sua Excelência manda que eu o manifeste assim a V.S., e eu tenho a honra e o prazer de fazê-lo.

Além de chamar em seu apoio ilustres dirigentes da República de Colômbia, o coronel José Concha apresenta a 26/06/1823 sua própria defesa em dez fólios [f. 107-117]. Embora o Fiscal não o acuse, ele prefere apresentar suas razões, satisfazendo aos membros do tribunal e provando a todos sua integridade, retidão e inocência.

Começa pela acusação feita por Teresa Laso, de ter estuprado com violência sua filha Rafaela Sandoval, que tem entre 18 e 20 anos. A denúncia não se acompanha por nenhuma prova e não foi confirmada pela própria vítima. As testemunhas se contradizem a propósito do local e da hora. O oficial Guerra afirma ter encontrado a Sandoval na rua, conduzida por um assistente, enquanto ela diz que encontrou os oficiais Martinez e Guerra à porta da sala. Tais lugares são absolutamente diferentes e estão separados por mais de 50 passos. Luz Bermúdez declara que Rafaela foi retirada da prisão pela meia noite, e trazida de volta na madrugada. Já os oficiais Ludovico e Guerra declaram que cumpriram a ordem de conduzi-la à sua casa por volta das nove e meia ou dez da noite, e que ela foi devolvida à prisão dentro de meia hora [sic].

A Sandoval foi levada à Intendência pelas $21 \mathrm{~h} 30 \mathrm{~min}$, por ordem verbal do general - em - chefe Pedro León Torres, para ser interrogada a respeito da conversa que teria tido naquela tarde com uma espiã do Inimigo. Tratava-se de obter informação acerca da tropa que ameaçava invadir a cidade. Ela prestou juramento na presença dos oficiais que a traziam; mas foi interrogada em separado, pois em tais circunstâncias cabe ao Chefe obter informação decisiva com rapidez. ${ }^{6}$

O general ordenara a averiguação secreta, e cabia a ele cumpri-la na condição de segundo Chefe militar. Um comunicado do tenente-coronel Tomás Cipriano de Mosquera ${ }^{7}$ fora amplamente divulgado, os civis estariam sujeitos ao foro militar em caso de delito de espionagem. Não lhe cabia questionar ou modificar o modo como lhe foi ordenado proceder pelo referido senhor general Torres; e o Governo a quem se deu conta aprovou aquela medida extraordinária, considerando sem dúvida que a Saúde da Pátria é a Suprema Lei, como consta do Certificado no 2 anexado ao processo.

Colocando-se ainda mais na situação de um réu ou de seu advogado diante do tribunal, o Intendente pergunta e responde, consultando tratados de criminalística ${ }^{8}$ : 
Pergunto eu agora, que diligências foram praticadas para averiguar o corpo deste delito? Não é bem sabido que o estupro ou defloramento deve qualificar-se mediante declaração jurada por duas matronas honestas e prudentes, e de conhecida probidade, que darão razão de tudo o que vejam e entendam? [...] Não é também constante na prática que as provas da violência devem buscar-se na comparação entre a idade da mulher acusadora e a do acusado, e entre a força física de ambos, como também dos sinais de violência que devem existir nas partes sexuais? [...] Nada disto consta do Sumário: não está justificado para o corpo de delito.

Tivesse ele a intenção de violentar a jovem, por que mandaria dois oficiais, futuras testemunhas, trazê-la à casa mais conhecida da cidade, às $20 \mathrm{~h} 30 \mathrm{~min}$, estando acordados todos os moradores, e presentes muitas pessoas? Com 18 a 20 anos, toda mulher tem suficientes forças para defender-se em tais circunstâncias. Caso tivesse ocorrido o estupro, por que a vítima não gritou para defender-se? Quando perguntaram ao oficial Guerra se, ao encontrar a Sandoval, trazida pelo soldado, ela estaria chorando ou soluçando, ou dando mostras de ter sofrido algum dano ou ultraje, ele respondeu: "A moça guardou um profundo silêncio até entrar na prisão e conversar com sua mãe durante cerca de cinco minutos, e somente depois disto é que a mãe começou a gritar contra mim, acusando-me [sic] de ter deflorado sua filha." [f. 108v]. Então, a dor física e moral se calou nesta mulher até depois de ter falado com sua mãe? Estaria adormecida quando sofreu a injúria?

E por que Teresa Laso não o acusou perante o general Torres, que era seu chefe imediato no comando do exército? Por que não apresentou sua queixa (em janeiro) a Sua Excelência o Libertador quando ele esteve pessoalmente em Cali? E por que só veio a fazê-lo em fevereiro, em Popayán? A razão é clara: inimiga irreconciliável do sistema de Liberdade, esta mulher tem conexões íntimas com certa Casa, de onde têm saído males incalculáveis sobre a desgraçada cidade de Popayán e sobre a província inteira. Em todas as épocas da República, Teresa Laso tem sido o canal utilizado por aquela Casa na comunicação de seus perniciosos projetos ao exército inimigo do Sul. ${ }^{9}$ Ela veio a ser o meio pelo qual a mesma Casa tenta desacreditar um Chefe Republicano incômodo, que goza de muito bom conceito entre os patriotas, comprovado pelos documentos anexados ao processo.

O Intendente José Concha conclui sua defesa em relação à primeira acusação (que inclui as supostas tentativas de estupro contra a sobrinha de Fernando Sánchez e contra Baltazara Bonilla), exigindo o rigor da lei contra Teresa Laso por suas falsas acusações: que ela pague as suas despesas causadas pelo processo, que seja multada e declarada infame por toda a 
vida. Passa ao segundo bloco de acusações, que teriam sido acolhidas por um juiz de Cali de uma forma irregular, equivalente aos antigos Juízos de Residência que já não são permitidos.

Quem o acusa são inimigos declarados seus, como José Núñez, a quem ele ameaçou fuzilar por proteger a deserção de dois filhos que ele mesmo apresentara como recrutas; ou Francisco Espinosa, repreendido pela crueldade com que tratava os seus escravos. Segundo as Leis de Partida (espanholas), os inimigos capitais não podem ser chamados como testemunhas; ao julgar administradores e funcionários públicos, devem ser convocadas testemunhas inatacáveis, para que os poderosos do lugar não aproveitem a ocasião vingando-se de quem cumpriu a lei. Ramón Cobo, por exemplo, quer vingar-se por ter sido intimado a pagar os impostos e empréstimos cobrados pelo Supremo Governo. O Intendente José Concha lembra que investigou a conduta do comandante Varela, acusado de acobertar delitos de militares e funcionários na província do Cauca, recebendo do Libertador um elogio muito honroso ao completar aquela tarefa [f. 112]. Cidadãos probos como José María Mosquera e o contador da Casa da Moeda Tomás Ayerbe ${ }^{10}$ declaram que ele tentou conter excessos, corrigir desmandos, etc. Quanto à acusação de excessiva simpatia pelos escravos, declara que, alertado pelo tenente coronel Fernando Fernández, Intendente de Raposo, ele convocou Francisco Espinosa e viu que os proprietários de barcos e de escravos queixavam-se com razão, pois não lhes pagavam pelo transporte de cargas e tropas que desciam a cordilheira para embarcar rumo a Quito. A maioria das queixas e acusações contra ele - em geral equivocadas - se reporta a operações de guerra, que não cabem neste processo de alçada civil, ou a funcionários de instituições não sujeitas à autoridade da Intendência.

Acusações graves de assassinatos, incêndios e roubos ocorridos na cidade de Anserma - aqui é citado o coronel Antonio Alaix - são objeto de outro processo, e escapam à jurisdição do Cauca. Quanto às acusações de roubo de cavalos nos anos 1820 e 1821 - aqui é citado o capitão José Ignacio Rengifo - os queixosos são egoístas que queriam reaver seus cavalos e mulas justamente quando as divisões patriotas se moviam contra o Inimigo. Estavam certos em reclamar, mas ele tinha ainda mais razão para mandar buscar mais animais em defesa da Saúde da Pátria. Os animais se perdiam ou se feriam, e era preciso substituí-los; os cabildos não atendiam aos seus pedidos e era forçoso procurar cavalos e mulas nas montanhas onde seus proprietários os escondiam. Muitas tropas atuaram na província de Popayán entre 1820 e 1822 e grandes recursos foram tomados aos habitantes, antes e 
depois que o Presidente Libertador requisitou 800 mulas e 400 cavalos para a marcha contra o Sul. Nestas incursões podem ter ocorrido excessos; os prejudicados deveriam ter exigido comprovantes legais das requisições, multas, impostos e outras exigências que sofriam, e encaminhado as suas reclamações aos órgãos competentes. Alguém aproveitou a ocasião para acusá-lo de violência contra três missionários franciscanos. Eles tinham abandonado suas tarefas na província de Antioquia; alertou o guardião da ordem, proibindo-os de vir a Cali. O problema se resolveu e o superior franciscano não formulou nenhuma queixa.

Volta à denúncia de simpatia ilimitada pelos escravos: tudo começou com um comunicado que ele publicou em Ibagué, ratificado no vale do Cauca por ordem do governo, oferecendo liberdade aos escravos que se alistassem nas tropas da República e prestassem serviço por três anos. Os escravos interpretaram mal a novidade, julgando-se livres de fato e de direito, não se alistando no exército e recusando-se a trabalhar. Ele procurou corrigir a situação e comunicou ao governo os inconvenientes criados por aquela ordem. O governo publicou decreto prescrevendo penas, inclusive a de morte, contra os escravos insubordinados. Não houve nenhum levante de escravos do vale do Cauca contra os seus amos, e os da costa foram contidos pela força das armas. ${ }^{11}$ Por outro lado, o decreto de 14/03/1822 reafirmou a Real Cédula de 1789: os procuradores gerais deveriam acolher as queixas dos escravos contra abusos de seus amos.

Acerca da acusação de concubinato, José Concha recorda ao tribunal o disposto na Recopilação das Leis de Índias a este respeito e apenas indica os documentos das principais autoridades civis e religiosas de Popayán e de várias outras cidades em seu apoio. Conclui reafirmando seu direito à recuperação de todas as despesas e prejuízos que teve com o processo, que devem ser pagos pelos responsáveis.

O veredicto da Corte Superior de Justiça foi inteiramente favorável ao coronel José Concha, Intendente do Departamento do Cauca. A Corte levou em conta a abundante documentação apresentada, que desqualificou as principais acusações feitas contra ele durante a ampliação do processo, bem como o grande número e a qualidade das testemunhas arroladas em sua defesa.

Ao tomar este processo como fio condutor para mais um ensaio de aproximação ao passado, impõe-se uma inquietação: o tema é relevante? Por que retirar dos labirintos do passado um processo escandaloso contra um dos heróis da independência?

O processo por estupro aberto por Teresa Laso contra o coronel José Concha mostra aspectos pouco discutidos da Independência. Nossa fonte 
traz para o primeiro plano a expressão escrita - juridicamente estereotipada - de gritos, falas, gemidos e silêncio, carregados de ressentimento. Se a guerra prolonga a política, este processo também aplica a lógica da guerra, que prosseguia alimentando rancores, exigindo mais e mais recrutas, gado, cavalos, suprimentos, dinheiro.

O processo de Independência aguçou as contradições entre as províncias da Governação de Popayán: as cidades do vale do Cauca organizaram-se em confederação enquanto o governador de Popayán Miguel Tacón contribuiu energicamente à repressão das juntas patrióticas de Quito. Desde os primeiros momentos, os índios da província de Pasto e os negros e mulatos do vale do rio Patía foram os mais empedernidos soldados realistas, derrotando vários generais e comandantes republicanos e, por isto, sofreram a duríssima vingança de Simón Bolívar, que até hoje não foi esquecida (PABÓn Díaz, 1995).

O suposto estupro que justificou o processo contra o Intendente José Concha teria ocorrido em julho de 1821; o processo foi aberto em fevereiro de 1822; e concluído em junho ou julho de 1823. Tratemos de contextualizar cada uma destas épocas, procurando compreender o repentino silêncio de dona Teresa Laso e de sua filha Rafaela Sandoval em meio a tantas palavras.

Certos antecedentes importantes se encontram nas memórias de Manuel José Castrillón (1781-1863), publicadas em 1868. Os patriotas tinham assumido o controle de Popayán em abril de 1811, incendiado o vilarejo de Patía em setembro e conquistado Pasto em outubro; mas, em fins de 1812 já reuniam suas últimas tropas para enfrentar o violento revide das forças realistas que haviam retomado Pasto em maio. Popayán sofria constantes ataques de guerrilheiros patianos. Castrillón Arboleda (1971, p. 102-103) aponta um núcleo de famílias monarquistas que estimulavam e apoiavam os guerrilheiros:

[...] os Gruezo, Rodríguez, Velasco, Olaves, Cajiao, os frades franciscanos e principalmente o senhor Francisco Diago, cuja casa era o arsenal e quartel general dos ferozes patianos. Dali saíam armas, munições, planos de ataque e notícias acerca de tudo o que o governo fazia e planejava. Os agentes para tais operações eram principalmente a Teresa Laso e seu marido Pedro Sandoval, pai do presbítero Teodoro Sandoval [...].

A casa da família Diago seria, então, uma cunha do dispositivo político e militar espanhol, estrategicamente situada entre a praça central de Popayán e o bairro do Egido, que era a passagem direta para o vale do Patía, para Pasto e para o Equador. É a famosa Casa referida mais tarde pelo

História Revista, Goiânia, v. 13, n. 2, p. 353-377, jul./dez. 2008 
Intendente José Concha como o local "de onde têm saído males incalculáveis sobre a desgraçada cidade de Popayán e sobre a província inteira”. Surpreende-nos a coincidência entre a lembrança tão nítida de Manuel José Castrillón (por volta de 1858) de Teresa Laso como a principal informante do inimigo em 1812, e as palavras de José Concha em 1823: "Em todas as épocas da República, ela [Teresa Laso] tem sido o canal utilizado por aquela Casa na comunicação de seus perniciosos projetos ao exército inimigo do Sul." Seria casual tamanho espelhamento entre os dois textos, separados por 33 anos?

Nenhum texto do processo fez qualquer referência à família de Teresa Laso e Rafaela Sandoval, geralmente chamadas "a Laso", "a Sandoval", como pessoas de ínfima categoria. Agora vemos que Teresa Laso era esposa de Pedro Sandoval, e que, além de Rafaela Sandoval, ela tinha um filho padre, Teodoro Sandoval. O coronel José Concha, que chegara a Popayán em 1820, não devia ignorar esses laços de família, mas insistiu em diluir Teresa e Rafaela na massa anônima das mulheres partidárias da monarquia espanhola, inimigas da República.

O coronel Concha escrevia em agosto de 1821 que para garantir a segurança de Popayán "seria preciso retirar todo o povo baixo, principalmente as mulheres." Em várias passagens de suas memórias, Castrillón critica a adesão da maioria das mulheres de Popayán à causa monarquista, cita várias delas e destaca o papel de Teresa Laso.

Temos acesso a textos desta época redigidos pelo bispo Don Salvador Jiménez Enciso Cobos y Padilla (1765-1841). Nascido em Málaga, viveu 20 anos no vice-reino do Rio da Prata onde entrou na vida eclesiástica; de volta à Espanha, combateu as tropas invasoras francesas e lutou pelos direitos de Fernando VII ameaçados pelas Cortes de Cádiz, recebendo por isto a diocese de Popayán; chega a seu destino em 05/08/1818, um ano antes da conquista de Bogotá pelas tropas patriotas comandadas por Simón Bolívar.

Popayán torna-se o principal centro da resistência realista contra a recém-criada República de Colômbia (1819). Don Salvador Jiménez apóia com afinco a contra-ofensiva do coronel espanhol Sebastián de Calzada e excomunga os patriotas. Apesar disto, a 24/10/1819 as tropas do coronel Joaquín París ocupam Popayán; os realistas retiram-se para Pasto; o bispo proíbe a administração dos sacramentos e suspende de suas funções os sacerdotes que não sigam com ele a Pasto. As autoridades da República de Colômbia, apoiadas pelo clero republicano, decretam o seu desterro e ordenam a eleição de um novo bispo. Seis meses depois, em abril de 1820, o coronel Calzada recupera Popayán, sempre apoiado por don Salvador 
Jiménez que retorna à sua cidade por dois meses apenas, sendo logo forçado a recuar novamente. Em outubro, o bispo comanda a grandiosa solenidade cívico-religiosa de juramento coletivo à Constituição Liberal da Monarquia Espanhola em Pasto.

Os realistas retomam Popayán em janeiro de 1821, até que retornam os patriotas, sob o comando do general Manuel Valdés, em 20 de julho. Cinco dias depois ocorre a prisão de mulheres suspeitas de espionar em favor dos realistas que ainda ameaçam a cidade; segue o interrogatório e, supostamente, o estupro da jovem Rafaela Sandoval pelo comandante militar José Concha e a deportação das presas a Cali e, dali, ao porto de Buenaventura na costa do Pacífico.

Em janeiro de 1821, o presbítero Félix Liñan y Haro, secretário de don Salvador Jiménez, envia ao Presidente da Audiência de Quito Melchor Aymerich a carta de um sacerdote relatando o estado em que se encontrava Popayán no dia 03/01/1820:

[...] os rebeldes que afligem a desgraçada Popayán estão amedrontadíssimos: os foguetes disparados na primeira Missa de Aguinaldo [novena que prepara o Natal] da igreja de San Camilo às quatro da manhã alarmaram os quartéis durante quase todo o dia, e as deserções não cessam. O contingente do inimigo de Popayán se compõe de [...] 340 homens, 28 oficiais, e 300 fuzis [...] (OrTIZ, 1984, p. 203-204)

Em outro informe, o bispo elogia a fidelidade dos 23 sacerdotes que ele designara recentemente para as paróquias do Vale do Cauca, apenas dois aderiram ao partido patriota. Manuel Pernías, de Anserma, foi preso e conduzido a Bogotá; sua esposa sofreu 300 açoites e a filha mais de 200, mas não confessaram onde estavam alguns oficiais do exército realista, escondidos pelo clero. A prática de açoitamento de mulheres reaparece mais adiante e desperta a nossa surpresa:

[...] em certa ocasião mandaram desterradas para Cali 14 mulheres, depois de açoitá-las desumanamente, e em seu tormento elas gritavam somente que amavam a seu Rei e Senhor [...]. (ORTIZ, 1984, p. 212)

Estaria o bispo de Popayán referindo-se a Teresa Laso, Rafaela Sandoval e suas companheiras? O documento é de 21/03/1820; a deportação que nos interessa ocorreu a 26/08/1821, quando os patriotas tomavam por fim a capital da província; embora assediados por algum tempo, nunca mais recuaram. Se Teresa Laso e Rafaela Sandoval tivessem sido açoitadas, 
por certo não omitiram tal fato, em meio a tantas acusações feitas contra o coronel José Concha. Ele mesmo indicou que houve pelo menos dois outros grupos de mulheres deportadas por outros comandantes.

A correspondência de don Salvador Jiménez durante a guerra contém equívocos e distorções, partidarismo, vontade de enaltecer a monarquia espanhola, as suas autoridades, o catolicismo dos fiéis de sua diocese. Mas parece evidente que a maioria da população simpatizava mais pela causa realista que pela independência:

[...] no dia do meu retorno, o povo inteiro saiu a receber-me a uma légua de distância com grandes demonstrações de amor [...] com igual júbilo receberam as tropas Reais e para demonstrar sua lealdade buscaram o Retrato de Vossa Mercê que antes ficava no Cabildo, e que eles tinham escondido de seus inimigos, colocando-o num Trono sob um dossel, acompanhando-o todo o povo com velas acesas, muita música, e, vestidos como índios, manifestando submissão e amor a seu idolatrado [rei] Fernando [VII]. Tal tem sido a conduta de Popayán, bem conhecida pelos rebeldes, cujo furor se excitou até o extremo de que o Governador insurgente [general Antonio] Obando havia decretado a degola da maior parte do Povo [...]. (OrTIZ, 1984, p. 213)

Nosso processo evoca a crueza da guerra nas províncias da antiga Governação de Popayán. A adesão das províncias meridionais - historicamente vinculadas à Audiência de Quito - à causa monárquica contrasta com o republicanismo das províncias setentrionais, as cidades do vale do rio Cauca, vinculadas à Audiência de Bogotá. O processo tem três momentos distintos, e três principais protagonistas.

No primeiro momento, fevereiro a maio de 1822, o protagonista central é Teresa Laso, membro da maioria monarquista de Popayán: mãe de uma família vinculada à Casa Diago, e personagem ativa do espaço sócioespacial do bairro do Ejido, fronteira aberta para as províncias do Sul. O processo foi aberto na primeira estadia de Simón Bolívar em Popayán (26/ 01 a 08/03/1822). O contexto era o de montagem frenética de uma nova ofensiva militar contra Quito. A iniciativa poderia ter o objetivo dissimulado de desestabilizar a retaguarda do exército patriota por meio da desmoralização do chefe político de Popayán. Note-se o empenho de Simón Bolívar em que se faça justiça.

Num segundo momento que segue a periodização do processo paralelo ao qual não temos acesso direto (15/04 a 27/08/1822), as vozes de Teresa Laso e de sua filha Rafaela Sandoval parecem dispensáveis. A lide- 
rança no combate ao Intendente José Concha passa à Corte de Justiça de Cali, que acolhe as mais variadas denúncias trazidas por fazendeiros e empresários do vale do Cauca. Enquanto isso, a ofensiva militar contra Quito se desenrola em duas frentes: o general Antonio José de Sucre avança a partir de Guayaquil, com tropas embarcadas no porto de Buenaventura, e Simón Bolívar enfrenta o duro caminho de Pasto. A falta de contato entre os dois contingentes favorece os realistas de Pasto que, sabendo já da ocupação de Quito pelas tropas de Sucre (25/05/1822), negociam a tempo uma rendição honrosa com Simón Bolívar. Na tarde de 8 de junho, o Libertador entra na cidade com o ritualismo dos imperadores romanos; seguido por seu estado maior, passa por duas alas de tropas que lhe apresentam as armas ao som de música triunfal. O bispo Salvador Jiménez com suas vestes pontificais o espera sob o pálio na Plaza Mayor; o general vitorioso desmonta e o bispo lhe dá a paz e o incenso conforme o ritual católico e o real protocolo espanhol. Conduz o Libertador sob o pálio até a igreja onde se canta o Te-Deum. Concluído o triunfo, o bispo e o clero acompanham o general até a porta do templo. Poucos dias depois, Simón Bolívar marcha rumo a Quito; a 17 de junho a população de Pasto jura solenemente obediência à Constituição da República de Colômbia. Bolívar se concentra em anexar Guayaquil à República da Colômbia; a 13 de Julho já está ali, duas semanas antes de entrevistar-se com o general argentino San Martín, para ganhar o privilégio de comandar a campanha do Peru. Em agosto, Simón Bolívar já está a caminho de Lima.

Não parece clara a alegada omissão de Teresa Laso quando lhe foi dado o direito de aprofundar suas denúncias, entre abril e agosto de 1822: talvez possamos esclarecer essa dúvida no processo paralelo aberto na Corte de Justiça de Cali. Mais obscura ainda é a afirmação feita pelo ministro fiscal da Corte Superior de Justiça, em maio de 1823, de que ela teria retirado a acusação de estupro. Teresa Laso e Rafaela Sandoval devem ter acompanhado passo a passo as notícias de Quito e Pasto e decidido - ou aceitado - recuar. Para elas, as conseqüências da adesão de don Salvador Jiménez à República devem ter sido mais graves que a rendição de Pasto. Efetivamente, a presença do bispo de Popayán no triunfo do Libertador e no juramento à Constituição em Pasto evidenciou que o bispo e os chefes militares e políticos da causa espanhola se dissociavam da população local, que permaneceria por algum tempo ainda refratária à causa republicana.

Escrevendo ao vice-presidente Francisco de Paula Santander a 10/ 07/1822, o presidente Simón Bolívar discorreu assim acerca de don Salvador Jiménez: 
[...] é homem de muito talento, tem uma lógica bem militar [...] creio que nos será útil [...] Ele estava com muito medo do povo de Popayán e do Cauca, e pediu-me que o mandasse a Cuenca [diocese equatoriana] por algum tempo, mas eu sugeri que ele fizesse uma visita espiritual ao Arcebispado de Bogotá, por lembrar-me do seu interesse em que todos vissem um Bispo sintonizado com a República, e também porque essa Igreja necessita uma cabeça que apareça com alguma importância na capital de Colômbia [...] o bispo de Popayán nos será muito útil, porque [...] é homem entusiasta e capaz de pregar pela nossa causa com o mesmo fervor como o fez em favor de Fernando VII, apoiando suas opiniões com sólidos princípios de direito público [...] ele já é muito bom colombiano. Mandei que o assistam em todo o trânsito por conta do Governo porque ele está aqui totalmente sem recursos. Com 6 ou 8 mil pesos que lhe passem anualmente, estará demasiado contente, e diz que se lhe derem a metade também aceitará [...] eu sou o protetor natural de minhas conquistas e vejo o bispo de Popayán como uma delas. (GARCÍA-HERRERA, 1961, p. 276-277)

O terceiro momento começa em outubro de 1822 com José Concha correndo à procura de apoio entre autoridades civis, eclesiásticas e militares, ganhando a simpatia do novo ministro fiscal e de Vicente Azuero na Corte Superior de Justiça, preparando uma peça eloqüente em sua própria defesa. O desfecho permite-nos compreender melhor o que esteve em jogo durante a conjuntura anterior, na profusão de denúncias recolhidas pelo juiz de Cali contra o Intendente José Concha no processo que correu em separado. Tais denúncias apontaram reais ou supostos desmandos cometidos no vale do Cauca por autoridades civis e militares ou por funcionários da República. Uma releitura dos dados estatísticos sistematizados por Zamira Díaz López (1983, p. 66-96) esclareceria talvez se as requisições forçosas de cavalos e mulas, gado, mão de obra, recrutas, impostos extraordinários, etc., foram mais severas durante os períodos de ocupação do vale do Cauca por tropas realistas ou patriotas. Mas encontramos nas memórias de Manuel José Castrillón a lógica desse contexto.

Capturado em Popayán pelos monarquistas em setembro de 1816 e cruelmente torturado, Castrillón foi absolvido em Bogotá e posto em liberdade em agosto de 1817. Reinstalou-se precariamente no vale do Cauca e voltou à militância patriótica a partir de setembro de 1819 , assumindo importantes tarefas administrativas em Popayán: Juiz de Seqüestros (de propriedades de realistas) e logo Visitador Geral de Rendas (circulando entre várias cidades). Em 19/03/1820 recebeu do vice-presidente Santander "o encargo de recolher o empréstimo imposto pelo Libertador às cidades da 
antiga província de Popayán, para poder iniciar sua marcha ao Peru" (CAstrillón Arboleda, 1971, p. 189). Observemos suas atividades:

[...] Muitas dificuldades enfrentei a princípio para fazer efetivos os 10.000 pesos designados àquela cidade [Cartago], mas sem extorquir e com meios prudentes recolhi tudo e comecei a enviar auxílios ao Governador [José] Concha, para que este cuidasse dos gastos públicos. Ele insistia muito por mais recursos, que eu fornecia ora em dinheiro, ora em cabeças de gado [...] cheguei a Cali a 24 de junho [1820] [...] tive de proporcionar munições, vestuários e todo tipo de equipamento de guerra, organizar matadouros [...]. (CASTRILlón ARBoledA, 1971, p. 190-191)sistia muito por mais recursos, que eu fornecia ora em dinheiro, ora em cabeças de gado, ora providenciando em Cali a organiza

Algo mais tarde, quando as tropas patriotas já haviam tomado Quito e Pasto, o coronel José Concha precisou deixar a Intendência para responder a um processo aberto contra ele "pelos injustos moradores de Cali":

[...] as acusações que lhe fizeram resultavam da energia e constância com que atuou para juntar recursos nas circunstâncias mais urgentes, cujas consequiências foram a salvação da pátria [...] mas não podiam perdoá-lo por ter devolvido a Popayán a condição de capital da província logo que o inimigo se retirou dali. Não omitiram nada para desacreditar um magistrado digno de outro tratamento e cevaram-se até mesmo em sua vida privada, que é de domínio exclusivo da Divindade. Eu tive de dar alguns testemunhos favoráveis à sua conduta pública, em homenagem ao mérito, à justiça e à sua honradez. (CASTRILLÓN ARBOLEDA, 1971, t. 2, p. 20-21)

Aqui se explica a semelhança entre o depoimento prestado por José Concha em 1823 e as memórias de Castrillón escritas em 1858. Sendo a principal autoridade encarregada das requisições, empréstimos e recrutamentos forçados, etc., Manuel José Castrillón era a pessoa mais qualificada para defender e assessorar o Intendente José Concha na desqualificação de Teresa Laso: uma mulher entre outras, uma espiã monarquista. Trinta e cinco anos depois, Castrillón silenciou em suas memórias a espinhosa história de Teresa Laso e Rafaela Sandoval e referiu-se apenas a ataques contra a vida privada de José Concha, evocando provavelmente a acusação de bigamia. Justificando talvez o silêncio acerca do suposto estupro de Rafaela Sandoval, Castrillón criticou severamente o general patriota Manuel Valdés. Após cometer vários escândalos em Cali, o general tentou em vão seduzir uma filha do monarquista Manuel García, honrado morador de Popayán. 
Furioso, teria mandado assassinar o prisioneiro. (CASTRILlón ArboledA, 1971, p. 198-199).

A voz do bispo Salvador Jiménez ajudou a eliminar por completo a questão da bigamia no processo contra o Intendente José Concha. Ele certamente conhecia e respeitava a lei espanhola sobre o assunto, e não havia nenhum protesto formal de um marido traído. (Na mesma época começava em Quito o romance entre Simón Bolívar e Manuela Sáenz, esposa do comerciante inglês James Thorne).

Esse depoimento favorável ao coronel José Concha é de 07/03/1823. Depois de passar dois meses em Bogotá, ele havia jurado na catedral sua submissão à Constituição e às leis da República em 22/09/1822 (GARCíAHerRera, 1961, p. 281-282). Uma carta de outubro indica como ele se sentia nessa nova situação:

[...] embora não tenha muito dinheiro, amanhã vou convidar an famille [sic] a todos os eleitores da Província que estão na cidade, com os quais estou muito ligado e nos tratamos com a maior amizade: todas as noites eles vêm à minha casa e temos umas tertúlias muito divertidas; lamento quando eles se vão e me sinto muito solitário, sendo meus principais tertuliantes o senhor José Diago, o médico doutor Joaquín Lagrao e algum outro que não passam de quatro. Desapareceu o muro que nos separava, e creio que atualmente não há nenhum bispo mais amado por todas as suas ovelhas $[\ldots] .{ }^{12}$

A referência enfática a José Diago surpreende, pois se trata de um filho de Francisco Diago, o chefe político dos monarquistas, cuja casa acolhia os inimigos da República. José Diago (que testemunhou em defesa de José Concha) e Agustín Sarasti (o promotor fiscal diocesano que fundamentou o depoimento do bispo a favor do Intendente) foram citados por Manuel José Castrillón como aliados dos guerrilheiros patianos em fins de 1812 [Castrillón Arboleda, 1971, tomo 1, p. 103-105]. Ao mencionar o fim das divergências, don Salvador Jiménez parece aludir não somente aos antigos adversários patriotas, mas também a seus mais fiéis companheiros realistas que devem ter hesitado antes de acompanhá-lo aderindo à nova ordem. Castrillón Arboleda (1971, p. 24), embora se referindo a um período um pouco posterior, confirma:

Este ilustre varão contribuiu muito naquela época para a reconciliação dos partidos [...] Alegre, festivo e condescendente, conquistou [...] todo o influxo e simpatia que havia perdido antes. 
Podemos agora compreender o desfecho do processo: os realistas acompanham o bispo Salvador Jiménez aderindo à República e, não somente deixam de acusar o Intendente José Concha pelo estupro de Rafaela Sandoval, mas passam a defendê-lo, entendendo que esta seria a melhor maneira de confirmar Popayán como a capital da província, contra os interesses rivais da cidade de Cali.

Mas dona Teresa Laso não fazia parte desse acordo, a julgar pela carta indignada que não deixou de ser lida pela Corte Superior de Justiça em abril de 1823: "Deus me deu ânimo para queixar-me do insulto que [José Concha] fez, forçando a minha pobre filha, e ainda que me matem tenho cumprido o que Deus e a religião que professo mandam" [f. 60]. Será preciso enfrentar o silêncio dos arquivos perguntando mais por uma jovem que se chamava Rafaela Sandoval.

The lost honour of Rafaela Sandoval in the Independence (Popayán, 1821-1823)

AвSTRACT: The process for rape started by Teresa Laso against colonel José Concha shows some not much discussed aspects of the Independence: the expression legally written referred to as cries, speeches, groans and silence, loaded of resentment. The process goes on while the war feeds more resentment, asking for more and more soldiers, cattle, horses, supplies, money.

KeY-words: Independence, Colombia, Popayán, Rape

\section{NOTAS}

1 O congresso constituinte reuniu-se em Cúcuta em julho de 1821; a constituição da República de Colômbia foi proclamada a 3 de outubro; os incidentes tratados neste processo ocorreram em julho de 1821.

1 Ao deixar seus postos, todos os funcionários e autoridades tinham os seus atos examinados, geralmente pelos seus sucessores, e deviam esperar no local o resultado de todos os processos abertos contra eles. Esta norma foi suprimida pela constituição liberal espanhola de 1812. Na América, ao contrário dos realistas, os patriotas desconheceram a constituição de Cádiz nos seus breves momentos de vigência.

2 Flores ou sementes de um arbusto que contém a substância alucinógena chamada escopolamina.

3 Archivo Central del Cauca - Signatura 6874 - Independencia M I - 3 j.

4 A Tesouraria Geral, uma dependência da Secretaria da Fazenda, foi criada em 08/10/1821, sob a direção de Juan de Dios Olano, ministro tesoureiro. 
5 Nesta passagem, José Concha parece admitir que empregou alguma violência no interrogatório, acumulando justificativas.

6 Tomás Cipriano de Mosquera era o chefe político e militar da cidade de Popayán desde agosto de 1820.

7 Entre outros: Gutiérrez (1805, p. 92).

8 O vice-reino do Peru, a Audiência de Quito, a província de Pasto, o vale do Patía, as terras comunais do Egido, o bairro do Egido...

9 Por esta mesma época, ao solicitar o cargo de Contador, tendo servido por muitos anos na Casa da Moeda, zelando por ela em momentos difíceis, Tomás Ayerbe anexou uma carta de recomendação do Governador General José Concha. Archivo Central del Cauca - Signatura 6238 CIII - 1f, n. 62 (Rотн Deubel, 2006, p. 291, nota 16).

10 Desde os primeiros conflitos, os realistas estimularam os escravos das minas de ouro da costa pacífica a revoltar-se contra os seus senhores, que eram os patriotas ricos de Popayán.

11 Archivo General de la Nación, Sección República, Fondo Curas y Obispos, tomo XXV, ff. 469-473.

\section{REFERENCIAS}

Almeida, Jaime de. O bispo de Popayán na memória da Independência. In: Costa, Cléria Botelho da (Org.). Um passeio com Clio. Brasília: Paralelo 15, 2002, p. 75-87.

Castrillón Arboleda, Diego. Manuel José Castrillón (Biografía y Memorias). Bogotá: Banco Popular, 1971.

DíAz López, Zamira. Guerra y economía en las haciendas: Popayán, 1780-1830. Bogotá: Banco Popular, 1983.

García-Herrera, Gustavo. Un obispo de historia: el obispo de Popayán Don Salvador Ximénez de Enciso y Cobos Padilla. Málaga: Caja de Ahorros, 1961.

Gutiérrez, Joseph Marcos. Capítulo 4. In: Gutiérrez, Joseph Marcos. Práctica criminal de España. Madrid: Oficina de Don Benito García y Compañía, 1805. V. 1.

Ortiz, Sergio Elias (Comp.). Colección de documentos para la Historia de Colombia (época de la Independencia): Primera serie. Bogotá: Editorial El Voto Nacional, 1984.

PABÓn Díaz, Ramiro. La fatídica e incomprendida guerra de Pasto: 1809-1824. Pasto: Graficolor, 1995.

Roth Deubel, André-Noël. La génesis del Estado republicano en Colombia: elementos para una historia social de la administración pública. Cuadernos de Historia del Derecho. Madrid, n. 13, p. 281-296, 2006.

Zuluaga, Francisco. La independencia en la Gobernación de Popayán. In: ValenCIA Llano, Alonso (Org.). Historia del Gran Cauca. Cali: Universidad del Valle, 1994. p. 104-111. 